\title{
Environmental impacts of food consumption by companion dogs and cats in Japan
}

Citation for published version (APA):

Su, B., \& Martens, P. (2018). Environmental impacts of food consumption by companion dogs and cats in Japan. Ecological Indicators, 93, 1043-1049. https://doi.org/10.1016/j.ecolind.2018.06.015

Document status and date:

Published: 01/10/2018

DOI:

10.1016/j.ecolind.2018.06.015

Document Version:

Publisher's PDF, also known as Version of record

Document license:

Taverne

Please check the document version of this publication:

- A submitted manuscript is the version of the article upon submission and before peer-review. There can be important differences between the submitted version and the official published version of record.

People interested in the research are advised to contact the author for the final version of the publication, or visit the DOI to the publisher's website.

- The final author version and the galley proof are versions of the publication after peer review.

- The final published version features the final layout of the paper including the volume, issue and page numbers.

Link to publication

\footnotetext{
General rights rights.

- You may freely distribute the URL identifying the publication in the public portal. please follow below link for the End User Agreement:

www.umlib.nl/taverne-license

Take down policy

If you believe that this document breaches copyright please contact us at:

repository@maastrichtuniversity.nl

providing details and we will investigate your claim.
}

Copyright and moral rights for the publications made accessible in the public portal are retained by the authors and/or other copyright owners and it is a condition of accessing publications that users recognise and abide by the legal requirements associated with these

- Users may download and print one copy of any publication from the public portal for the purpose of private study or research.

- You may not further distribute the material or use it for any profit-making activity or commercial gain

If the publication is distributed under the terms of Article $25 \mathrm{fa}$ of the Dutch Copyright Act, indicated by the "Taverne" license above, 
Original Articles

\title{
Environmental impacts of food consumption by companion dogs and cats in Japan
}

\author{
Bingtao Su*, Pim Martens \\ International Centre for Integrated Assessment and Sustainable Development (ICIS), Maastricht University, P.O. Box 616, 6200 MD Maastricht, The Netherlands
}

\section{A R T I C L E I N F O}

\section{Keywords:}

Ecological paw print

Greenhouse gas emission

Energy consumption

Environment

Companion animals

\begin{abstract}
A B S T R A C T
In Japan, there are more than 20 million companion dogs and cats that consume resources. Yet, little is known about their environmental impacts and the related energy policies aiming to reduce such impacts. In this study, we quantified Japanese companion dogs and cats' environmental impacts regarding their food consumptions. More specifically, we analyzed their dietary "ecological paw print" (EPP), greenhouse gas (GHG) emissions and energy consumption. Our results showed that the dietary EPP of an average-sized dog was 0.33-2.19 ha per year, which was equivalent to one Japanese people's dietary "ecological footprint" (EF) in a year. The dietary EPP of an average-sized cat was lower with $0.32-0.56$ ha per year. All companion dogs and cats in Japan could consume about 3.6-15.6\% of the amount of food that Japanese people do and release 2.5-10.7 million tons of GHG through their diet in a year. Many companion animals (particularly medium-sized and large dogs) consumed more energy than they actually needed to sustain their normal activity. By providing direct data on food consumption, this study gained an insight into the future of possible energy policies to reduce Japanese companion animals' environmental impacts.
\end{abstract}

\section{Introduction}

Achieving sustainability has become an issue of global concern for policy and decision makers as a result of the realization of the impacts the activities of humans have on the environment (Alshuwaikhat and Abubakar, 2008). Sustainability can be described as providing sufficient energy and resources required to maintain good health in a population without compromising the ability of future generations to meet their resource needs (Mani et al., 2016; Ahmadi et al., 2017). Over the last few decades, Japan has witnessed a substantial growth in its economic development, which, in turn, has increased the national demand for energy. Therefore, Japan has also witnessed a large environmental degradation problem (Rafindadi, 2016). While the nexus of the relationship between environmental degradation and energy consumption has been thoroughly studied by Japanese researchers (Galli et al., 2014; Iguchi and Koga, 2015; Lilja et al., 2015; Rafindadi, 2016), very few studies have been conducted documenting animals especially companion animals' environmental impacts and their correlation with sustainable development.

Dogs and cats are the two most common household companion animals and they are an integral part of the human society in Japan (Su et al., 2018). They play an important role due to their positive impact on both the psychological and physical health of people with whom they have contact (Swanson et al., 2013; Su and Martens, 2017). Psychological benefits include reducing stress levels, increasing self-esteem in children and adolescents and decreasing depression associated with spousal loss. Physical benefits include increasing physical activity, reducing blood pressure and risk of heart disease and decreasing medical expenses (Allen et al., 1991; Serpell, 1991; Headey, 1999; Headey et al., 2002). For companion animal owners, feeding is a significant way of demonstrating a caring and loving relationship with their animals (Fleeman and Owens, 2007). Many companion animal owners prefer to give their animals nutrients in excess of minimum recommendations, or use ingredients that compete directly with the human food system, which presents challenges in optimizing the sustainability of the pet food system and pet ownership (Swanson et al., 2013). Therefore, it is imperative to quantify companion animals' environmental impacts and evaluate how the pet food system can sustainably support the nutrition of the growing population of companion animals not only in Japan but also in other countries.

The "Ecological Footprint" (EF) is a mature aggregated indicator of environmental sustainability (Rees, 1992; Wackernagel, 1994; Wackernagel and Rees, 1998). It is often used for the analysis of human demand on natural resources and it capsulizes a wide range of environmental data into a single indicator (Ulucak and Lin, 2017). According to its definition, the EF is the amount of land that would be

\footnotetext{
* Corresponding author.

E-mail address: Bingtao.Su@maastrichtuniversity.nl (B. Su).
} 
required to provide the resources and absorb the emissions of humanity (Wackernagel and Rees, 1998; González-Vallejo et al., 2015). The dietary "Ecological Paw Print" (EPP) was originated from the EF, and it indicates the amount of land that would be required to provide the food resources for animals.

In Japan, there are more than 20.3 million companion dogs and cats that consume, as a significant portion of their diet, animal products and thus potentially constitute a considerable dietary EPP, greenhouse gas (GHG) emission and energy consumption (Keyzer et al., 2005; Swanson et al., 2013; Mullis et al., 2015; Okin, 2017). Animal production, compared to plant crops, requires greater land to produce equivalent protein energy and contributes to more GHG emissions and soil erosion (Wirsenius et al., 2010; Tilman et al., 2011; Okin, 2017). Given the significant environmental impact of meat production, prior studies have reported the enormous energy requirement of dogs and cats (Bermingham et al., 2010; Swanson et al., 2013; Bermingham et al., 2014; Mullis et al., 2015; Okin, 2017). Results showed that the resource consumption by dogs and cats could result in significant environmental impacts, such as GHG emission and feces production. The energy consumption of dogs and cats in the United States is equivalent to one-fifth of the US population' energy consumption (Okin, 2017). Further studies show that the EPP of a cat is equal to $2 \%$ of the average British person's $\mathrm{EF}$ (Ravilious, 2009), while the dietary EPP of some large dog breeds is as high as the $\mathrm{EF}$ for individuals in some undeveloped countries in the world (Vale and Vale, 2009; Schwartz, 2014). Additionally, due to the overfeeding, animal obesity has become a common health problem of dogs and cats, with the consequence of food waste and environmental degradation (Fleeman and Owens, 2007; Linder and Freeman, 2010; Swanson et al., 2013; Okin, 2017). Nevertheless, very few studies aim to investigate the dietary EPP and GHG emissions of companion animals from energy policy perspectives, particularly in Asian countries, such as Japan.

This study was designed to quantify the dietary EPP, GHG emissions, and energy requirement for companion dogs and cats in Japan. The goal of this study was to evaluate the scale of these animals' dietary resource consumption and to gain an insight into the future of possible energy policies in order to reduce their environmental impacts. The number of companion dogs and cats is increasing in Japan, and simultaneously a trend toward increasing meat quantity and quality in pet foods has occurred. As a possible consequence, the potential environmental impacts of companion dogs and cats might increase, which will eventually influence Japanese sustainable development in a negative way. Through this study, we aim to improve companion animal owners and even the whole Japanese people's awareness of environmental protection, to provide policy recommendations, and to balance companion animals' mission in emotional value creation and influence on environmental degradation.

\section{Methods}

\subsection{The dietary ecological footprint (paw print) of companion dogs and} cats

The method used to calculate the dietary EPP of companion animals in Japan was the componential method based on the calculation of the EF (Wackernagel and Rees, 1998). The EF is an indicator for quantifying man-land relations from the perspective of human consumption and is therefore a demand-side calculation method (Ferng, 2014). Calculating the EF from the perspective of population consumption demand is one of the most important components of the "Ecological Footprint Analysis" (EFA) approach (Ferng, 2014; Miao et al., 2016). The EFA has been used widely for fundamental studies of sustainable development (Lambrechts and Van Liedekerke, 2014; Liu et al., 2017) and it categorizes bio-productive land into six types: arable land, grazing land, forest land, fishing grounds, built-up land and energy land (Wackernagel and Rees, 1998; Geng et al., 2014). Companion animals' dietary EPP calculation is based on per capita (dog/cat) commercial dry food consumption. Considering that chicken is commonly used as the main source of protein and fat, while cereal (maize, wheat and rice) is the main source of carbohydrate in animal food in Japan, we only considered arable land and grazing land when calculating the EPP in the present study.

To simplify the calculation process, we assumed that the crude protein and fat were from chicken, and the carbohydrate was from cereals. We used the raw chicken and cereal in the calculation process, and the equation of the raw chicken and cereal is as shown below:

$R_{i}=\frac{I_{c} \times F}{I_{r}}(i=1,2)$

Where,

$i=$ the number of consumption items $R_{i}=$ raw ingredients of item $i$ $\mathrm{kg}$ ); $I_{c}=$ percentage of ingredients in commercial food; $F=$ total food consumption (kg); $I_{r}=$ percentage of ingredients in raw food.

According to the data from the Food Composition Databases, The United States Department of Agriculture (USDA), the average percentages of protein and fat in raw whole chicken are $17.33 \%$ and $17.98 \%$, while the average percentage of carbohydrate in raw cereal is $73.3 \%$. The proprietary nature and incredible variety of pet food recipes make an exact calculation impossible (Okin, 2017). Hence, calculations in this part were made on the assumptions that 1) the weight of protein and fat in raw chicken and carbohydrate in raw cereal did not change during the process of industrial production (the conversion rate is one to one) and 2) these raw ingredients make up nearly all of the mass of the pet food.

The main steps of the EPP calculation method are as follows:

First, the per capita EPP component of each consumption item should be calculated by the equation below (Du et al., 2006):

$A_{i}=C_{i} / Y_{i}(i=1,2)$

Where,

$i=$ the number of consumption items; $A_{i}=$ per capita EPP component of itemi; $C_{i}=$ per capita consumption of item $i(\mathrm{~kg}) ; Y_{i}=$ a yield factor for the $i$ th type of land, it represents the annual average productivity in the world of item $i(\mathrm{~kg} / \mathrm{ha})$.

Then, the equation of the per capita EPP is as shown below (Du et al., 2006; Liu et al., 2017):

$E P P=\sum_{i=1}^{n} r_{i} A_{i}$

Where,

$r_{i}$ is equivalence factor.

To align the measurement units, the two land types should be converted using an equivalence factor. The equivalence factor is the ratio of the average productive capacity of an area and the world (Wackernagel et al., 1999; Liu et al., 2017).

\subsection{The greenhouse gas (GHG) emission}

The GHG emission is related to global warming and climate change (Francke and Castro, 2013), and it is often used to assess the impact of human activities on the environment (Qu and Li, 2013). Companion animals also contribute to the GHG emissions through their energyrelated behaviors, such as eating and residing. In the present study, we mainly focused on their GHG emissions from food consumption.

The per capita GHG emission of companion animals is calculated as follows (Xu and Lan, 2017):

$\mathrm{GHG}=\sum I_{i} \times E I_{i}$

Where,

$i$ is the items of the food inputs, $I_{i}$ is the food inputs of item $i(\mathrm{~kg}), E I_{i}$ is the GHG emission intensity for the food commodities $\left(\mathrm{kg} \mathrm{CO}_{2} / \mathrm{kg}\right)$ 
Table 1

The greenhouse gas (GHG) emissions for the food commodities (Nemecek et al., 2012; Gerber et al., 2013).

\begin{tabular}{ll}
\hline Food category & GHG emission intensity $(\mathrm{kgCO} 2 \mathrm{eq} / \mathrm{kg})$ \\
\hline Poultry Meat & 5.40 \\
Cereal & 1.15 \\
Maize & 0.49 \\
Wheat & 0.58 \\
Rice & 2.38 \\
\hline
\end{tabular}

Note: the GHG emission of cereal was the average score of maize, wheat and rice.

(Table 1).

\subsection{The energy requirement}

The Resting Energy Requirement (RER) reflects the minimal amount of energy required daily to maintain body weight in the absence of factors such as exercise or environmental temperatures which could increase energy needs. It is a function of metabolic body weight and can be calculated using the formula (Fleeman and Owens, 2007):

$R E R($ Kcal/day $)=70 \times\left(B W t_{k g}\right)^{0.75}$

The Maintenance Energy Requirement (MER) is defined as the energy required to meet the basal metabolic rate plus the energy needed to support minimal activity and energy excretion (Milligan and Summers, 1986; Kaushik and Médale, 1994).

The following is a guide to the calculation of MER for companion dogs and cats.

For companion dogs (Fleeman and Owens, 2007; Linder and Freeman, 2010; Thatcher et al., 2010):

$M E R_{\operatorname{dog}}=1.39 \times R E R$

For companion cats (Flynn et al., 1996; Linder and Freeman, 2010; Thatcher et al., 2010; Jones and Ackerman, 2016):

$M E R_{\text {cat }}=1.27 \times R E R$

The coefficients of MER (1.39 for dogs and 1.27 for cats) were calculated according to the results from Linder and Freeman (2010).

\subsection{Data collection}

The paper-based and online questionnaires were distributed throughout Japan in 2015. The paper questionnaires $(n=146)$ were conducted using the authors' networks by means of snowball sampling (Goodman, 1961), while the online questionnaire $(n=400)$ was conducted via Cross Marketing, one of the pioneer research companies in Japan, by means of simple random sampling (Tillé, 2006). A total of 546 dog and cat owners were obtained throughout all the 47 prefectures of Japan. In the questionnaire, respondents were asked to supply information about their companion animals' basic characteristics (species, breed, gender, size, age, neutered status and health conditions), as well as their husbandry practices (How often and how long do you go for a walk with your dog?; How often does your cat go outside?; How often and how much do you feed your dog or cat?). Respondents were also asked whether they have other pets, and how many years they have owned their pets.

Additionally, we reviewed the secondary sources of information from the Japan Statistical Yearbook, government reports, statistical reports, published papers, international organizations and web pages. The nutritional components and calorie content of commercial animal food (see Table 2) were calculated according to the data from Purp Corporation and ten reputed animal food brands (Iams, Science diet, Jiwi Peak, Schupremo, Super gold, Natural choice, Pinnacle, Pro Plan, Eukanuba and Royal Canaan) in Japan.
Table 2

The percentage of ingredients and the calorie content in commercial animal food (chicken-based).

\begin{tabular}{lll}
\hline & Dog food & Cat food \\
\hline Protein (\%) & 25.67 & 26.00 \\
Fat (\%) & 14.67 & 7.50 \\
Ash (\%) & 8.00 & 8.00 \\
Fiber (\%) & 3.83 & 6.25 \\
Moisture (\%) & 10.00 & 10.00 \\
Carbohydrate (\%) & 37.83 & 42.25 \\
Calorie (kcal/kg) & 3533.3 & 3445.0 \\
\hline
\end{tabular}

Note: data were calculated according to the information from ten reputed animal food brands in Japan.

Table 3

The annual average productivity and equivalence factor of different land types.

\begin{tabular}{llll}
\hline Items & Annual average productivity & Equivalence factor & Land type \\
\hline Poultry & 33 & 0.5 & Grazing land \\
Cereal & 2744 & 2.8 & Arable land \\
\hline
\end{tabular}

Data on land use for average productivity and equivalence factors were taken from the United Nations Food and Agriculture Organization (FAO), National Bureau of Statistics and published papers (Table 3) (Wackernagel and Rees, 1998; Wackernagel et al., 1999; Shi et al., 2015; Liu et al., 2017). These factors were used to calculate the EPP components of grazing land and arable land.

\section{Results}

\subsection{Animal demographics}

In total, 546 completed surveys were received $(63.0 \%$ from dog owners and $37.0 \%$ from cat owners). The information that we collected from companion dog and cat owners includes their animals' species, gender, age, size, food consumption, health condition, sterilization condition and activity time (Table 4).

3.2. The individual dietary ecological paw print (EPP) and greenhouse gas (GHG) emissions of companion dog and cat in Japan

Our results showed a range of dietary EPP and GHG emissions of companion dogs and cats regarding their commercial dry food. On the whole, dogs (particularly medium-sized and large dogs) have a larger impact than cats, both in terms of the dietary EPP and GHG emissions. Dog's size has an important impact on food consumption, as well as the dietary EPP and GHG emissions, the larger the dogs, the more the food consumption and the stronger the environmental impacts. Assuming the average lifespan of a dog is 12 years and a cat is 14 years, then the dietary EPP of an average-sized dog and cat in their lifetime is 4.01-26.28 ha and 4.46-7.80 ha, which is responsible for the release of up to 1.52-9.97 and 1.69-2.96 tons CO2e GHG, respectively (Table 5).

3.3. The total dietary ecological paw print and greenhouse gas emissions of Japanese companion dogs and cats

According to the latest survey data from the Japan Pet Food Association, there were 10.35 million companion dogs and 9.96 million companion cats in Japan in 2014. The estimated dietary EPP of all companion dogs and cats in 2014 in Japan was 6.6-28.3 million ha, which was responsible for up to $2.51-10.70$ million tons of GHG emissions (Table 5). The Japan Statistical Yearbook and the latest version of EUREAPA showed that the per capita dietary EF of Japanese people was 1.43 ha and the per capita GHG emissions regarding food consumption by Japanese people were 2.16 tons in 2014 . Therefore, the total dietary 
Table 4

Companion dogs and cats' basic information of gender, age, size, food consumption, health condition, sterilization condition and activity time.

\begin{tabular}{|c|c|c|}
\hline & Dog: N (\%) & Cat: N (\%) \\
\hline Animal species & $344(63.0)$ & $202(37.0)$ \\
\hline \multicolumn{3}{|l|}{ Gender } \\
\hline Male & $198(58.4)$ & $90(44.6)$ \\
\hline Female & $141(41.6)$ & $111(55.0)$ \\
\hline \multicolumn{3}{|l|}{ Age } \\
\hline$<5$ years & $73(21.2)$ & $64(31.7)$ \\
\hline $5-10$ years & 151 (43.9) & $66(32.7)$ \\
\hline$>10$ years & $120(34.9)$ & $72(35.6)$ \\
\hline \multicolumn{3}{|l|}{ Size } \\
\hline Small $(1.5-10 \mathrm{~kg})^{1}$ & $226(41.4)$ & - \\
\hline Medium-sized (10-25 kg) & $96(17.6)$ & - \\
\hline Large $(25-59 \mathrm{~kg})^{2}$ & $22(6.4)$ & - \\
\hline \multicolumn{3}{|l|}{ Food consumption } \\
\hline $\begin{array}{c}\text { Dog: }<10 \text { g.BW }{ }^{-1} \cdot \text { day }^{-13} \\
\text { Cat: }<50 \text { g.day }\end{array}$ & $115(35.4)$ & $40(20.7)$ \\
\hline $\begin{array}{l}\text { Dog: } 10-25 \text { g.BW } \\
\text { Cat: } 50-100 \text { g.day }^{-1}\end{array}$ & $126(38.8)$ & $89(46.1)$ \\
\hline $\begin{array}{c}\text { Dog: }>25 \text { g.BW }{ }^{-1} \cdot \text { day }^{-1} \\
\text { Cat: }>100 \text { g.day }{ }^{-1}\end{array}$ & $13(4.0)$ & $10(5.2)$ \\
\hline No idea & $71(21.8)$ & $54(28.0)$ \\
\hline \multicolumn{3}{|l|}{ Health condition } \\
\hline Good & $195(56.7)$ & $110(54.5)$ \\
\hline Fair & $133(38.7)$ & $86(42.6)$ \\
\hline Bad & $16(4.7)$ & $6(3.0)$ \\
\hline \multicolumn{3}{|l|}{ Sterilization condition } \\
\hline Neutered & $180(53.4)$ & $177(87.6)$ \\
\hline Sexually intact & $157(46.6)$ & $25(12.4)$ \\
\hline \multicolumn{3}{|l|}{ Activity time } \\
\hline Dog: < 1 h, Cat: Never & $267(80.7)$ & $152(75.2)$ \\
\hline Dog: 1-2 h, Cat: Sometimes & $57(17.2)$ & $23(11.9)$ \\
\hline Dog: $>2$ h, Cat: Whole day & $7(2.1)$ & $26(12.9)$ \\
\hline
\end{tabular}

Note:

1 The Chihuahua is the smallest dog breed in the world (as well as in this study) (Knowler et al., 2017) and The Fédération Cynologique Internationale (FCI) standard state that an adult Chihuahua in general not weight less than $1.5 \mathrm{~kg}$. Therefore, we set the minimum value for dog weight as $1.5 \mathrm{~kg}$.

2 The Akita is the largest dog breed in our study, and an adult Akita generally not weight more than $59 \mathrm{~kg}$ (American Kennel Club). Therefore, we set the maximum value for dog weight as $59 \mathrm{~kg}$.

3 The minimum resting energy requirement for a companion dog is $25.3 \mathrm{kal} \mathrm{kgBW}^{-1}$.day ${ }^{-1}$, which means Japanese dog owner should give their dog at least $7 \mathrm{~g} . \mathrm{kg} \mathrm{BW}^{-1}$.day $^{-1}$ of chicken-based dry food to keep their dog in good or fair health condition $(95.3 \%$ respondents reported their dog's health condition as good or fair). Therefore, we set the minimum value for dog food consumption as $7{\mathrm{~g} . \mathrm{BW}^{-1}}^{-1}$ day $^{-1}$.

4 The minimum resting energy requirement for a companion cat is 117.7 kcal.day $^{-1}$, which means Japanese cat owner should give their cat at least 34 g.day ${ }^{-1}$ of dry food to keep their cat in good or fair health condition (97\% respondents reported their cat's health condition as good or fair). Therefore, we set the minimum value for cat food consumption as 34 g.day $^{-1}$.

EPP of dogs and cats was equal to the entire dietary EF of 4.62-19.79 million Japanese people, while the GHG emissions of total dogs and cats were equal to 1.17-4.95 million Japanese people's GHG emissions regarding their food consumption.

\subsection{Companion animals' energy requirement}

Our findings showed that large dogs' energy consumption to a great extent exceeded their resting energy requirement. Most companion dogs, particularly medium-sized and large dogs, consumed more energy than they actually needed to sustain their normal activity, although there were some floor effects that made the minimum energy consumption lower than the minimum MER. The energy consumption by companion cats was sufficient to sustain their MER (Table 6).

\section{Discussion}

The Japanese national EF accounts show that household resource consumption is in a state of overshoot, demanding more capacity than the biosphere can supply each year. Companion animals provide important therapeutic, physiological and psychological benefits to humans and nowadays they are often regarded as family members by their owners (Okin, 2017). Their various activities taking place within families exaggerate household resource consumption and may have some serious direct and indirect impacts on the environment. The aims of the present study are to measure companion animals' environmental impacts caused by their food consumption by quantifying their dietary EPP, GHG emissions and energy consumption and simultaneously provide some suggestions on the possible energy policies to reduce such environmental impacts. Our results indicate that the huge number of companion dogs and cats in Japan contributes to a significant food consumption and environmental degradation. Reducing their resource consumption and environmental impacts requires complex strategies and decisions on how the total dietary EPP and GHG emissions need to shrink. Using quantitative variables such as the dietary EPP, GHG emissions and energy consumption, targets can be set and progress measured towards reducing demand for land capacity (Kitzes et al., 2008). Policy regulations such as impose tax burdens on owners, control companion animal numbers and encourage technological innovations on alternative energy sources would be considered as key driving forces for reducing companion animals' environmental impacts.

\subsection{Dietary ecological paw print (EPP)}

An important way to assess the relationship between companion animals' food consumption and environmental degradation is through the concept of the dietary EPP. Our results demonstrate that one medium-sized dog's dietary EPP was even larger than one Japanese people's dietary EF and two medium-sized dogs or one large dog's dietary EPP was equivalent to one Japanese people's whole EF (5.25 ha). This finding reveals that companion animals could consume a large amount of food resources, which are important components of household resource consumption and should be included when calculating the household EF and the national EF in Japan. Large dogs' food consumption is undoubtedly higher than small dogs and cats. Our results indicate that a large dog's dietary EPP is equivalent to around nine small dogs or 12 cats' dietary EPP. Both small and large animals have been demonstrated to be related to important benefits, such as companionship, friendship and opportunities to learn responsibility (Blue, 1986; Kidd and Kidd, 1998). Therefore, reducing the rate of large dog ownership and in favor of small dogs and cats that can offer similar benefits would be an efficient way to reduce the overall dietary EPP of companion dogs and cats in Japan.

According to our calculation, the dietary EPP of all companion dogs and cats was equivalent to $4.62-19.79$ million Japanese people's dietary EF. In addition to the huge number of companion dogs and cats, the high percentage of animal products in pet food is another important reason for the high dietary EPP of companion animals in Japan. Animal production requires more land compared to plant crops to produce the same protein energy (Reijnders and Soret, 2003). However, meat consumption, already high in human food, is still increasing in pet food. Previous studies indicate that meat alternatives (e.g., artificial meat, vitro meat) have the advantages of requiring less arable land and minimalizing the negative environmental impacts (Hopkins and Dacey, 2008; Hocquette et al., 2015). Therefore, replacing animal products with alternatives might be a choice for the pet food industry in the near future. The potential of the technological development and the need for investment in artificial meat and other meat alternatives should be emphasized in order to reduce animal products' negative impacts on the environment (Vinnari, 2008). Additionally, according to our findings about the large range of the dietary EPP, we suppose overfeeding would 
Table 5

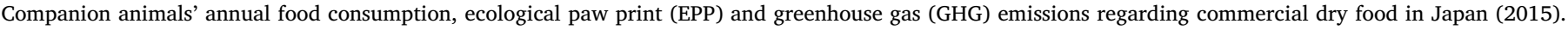

\begin{tabular}{|c|c|c|c|}
\hline & Food consumption (kg/year) & EPP (ha/year) & GHG emissions (ton CO2e/year) \\
\hline One average-sized dog & $18.75-122.80$ & $0.33-2.19$ & $0.13-0.83$ \\
\hline Small dog & $5.04-60.83$ & $0.09-1.09$ & $0.03-0.41$ \\
\hline Medium-sized dog & 35.19-191.35 & $0.63-3.41$ & $0.24-1.29$ \\
\hline Large dog & $96.38-498.00$ & $1.72-8.88$ & $0.65-3.37$ \\
\hline \multirow[t]{2}{*}{ One average-sized cat } & $17.88-31.25$ & $0.32-0.56$ & $0.12-0.21$ \\
\hline & Food consumption (Kg) & EPP (ha) & GHG emissions (ton CO2e) \\
\hline One dog (lifetime 12 years) & $225.00-1473.60$ & $4.01-26.28$ & $1.52-9.97$ \\
\hline \multirow[t]{2}{*}{ One cat (lifetime 14 years) } & $250.32-437.50$ & $4.46-7.80$ & $1.69-2.96$ \\
\hline & Food consumption (million kg/year) & EPP (million ha/year) & GHG emissions (million ton $\mathrm{CO} 2 \mathrm{e} /$ year) \\
\hline Total dog & $194.1-1271.0$ & $3.4-22.7$ & $1.31-8.60$ \\
\hline Total cat & $178.1-311.3$ & $3.2-5.6$ & $1.20-2.10$ \\
\hline
\end{tabular}

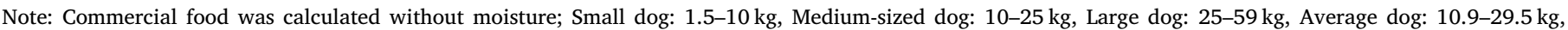
Average cat: $2-6 \mathrm{~kg}$. The estimated dog and cat population in Japan was 10.35 and 9.96 million in 2014 (Japan Pet Food Association).

\section{Table 6}

The resting energy requirement (RER), maintenance energy requirement (MER) and energy consumption of companion dogs and cats in Japan in 2015.

\begin{tabular}{clll}
\hline & RER/year (Kcal) & MER/year (Kcal) & $\begin{array}{l}\text { Energy consumption/ } \\
\text { year (Kcal) }\end{array}$ \\
\hline $\begin{array}{c}\text { One average- } \\
\text { sized dog }\end{array}$ & $153271-323413$ & $213047-449544$ & $66249-433889$ \\
$\begin{array}{c}\text { Small dog } \\
\text { Medium-sized }\end{array}$ & $34631-143678$ & $48136-199713$ & $17808-214931$ \\
$\quad$ dog & $143678-285658$ & $199713-397064$ & $124337-676097$ \\
$\begin{array}{c}\text { Large dog } \\
\text { One average- } \\
\text { sized cat }\end{array}$ & $285658-543914$ & $397064-756040$ & $340539-1759583$ \\
& & $54572-124396$ & $61597-107656$ \\
\hline
\end{tabular}

Note: Small dog: 1.5-10 kg, Medium-sized dog: 10-25 kg, Large dog: 25-59 kg, Average dog: 10.9-29.5 kg, Average cat: $2-6 \mathrm{~kg}$.

exist among companion animal owners in Japan. To ensure feeding of appropriate amounts in order to avoid food waste and reduce the dietary EPP, we suggest owners using accurate methods to determine portion sizes such as with electronic scales (Bermingham et al., 2014).

In view of companion animals' significant impact on resource consumption and land use, we consider that scientific evaluation of companion animals' dietary EPP may provide valuable insights to policymakers so that sustainable development patterns can be recognized (Geng et al., 2014). The dietary EPP accounts as a detailed resource accounting tool can be used to analyze aggregate companion animals' pressure on ecosystems. Therefore, appropriate policies, such as changing animal food systems and finding alternative sources of protein, should be raised by considering companion animals' dietary EPP, nutritional requirement and environmental impacts.

\subsection{Dietary greenhouse gas (GHG) emissions}

We examined the GHG emissions associated with companion animals' daily diets and the results demonstrate that all companion dogs and cats in Japan release 2.52 to 10.70 million tons of GHG through their diet in a year, which is equivalent to $1 \%$ to $4 \%$ (one to five million) Japanese people's environmental impacts according to their annual diet. These issues of companion animals' environmental pressure are easily neglected by researchers and decision makers. Nevertheless, without any doubt, their continuously increasing ecological pressures will make management of demand on and supply of ecological capacity one of the central concerns in Japan and even the whole world (Kitzes et al., 2008).

In order to guide further initiatives within companion dog and cat household operations, a set of scenarios should be developed in order to lower the GHG emissions. Companion animal obesity can be defined as a condition of excessive energy storage, and it is quite a prevalent phenomenon in many developed countries including Japan (Courcier et al., 2010). Actually, many companion animal owners' fairly restricted knowledge about the feeding directions results in their activity of overfeeding. Therefore, the scenarios pointed out that priority should be given toward overfeeding and food waste. Veterinarians play a critical role in optimal pet body weight by educating owners on the selection of appropriate pet food. They can provide specific knowledge on assessing animals' body and health conditions, according to which give recommendations about the amount to feed. Additionally, previous studies demonstrated that an animal consuming animal-based diets causes more GHG emissions than the GHG emissions associated with consuming the same number of calories, but from plant sources (Eshel and Martin, 2006). Therefore, the environmental degradation caused by companion animals in the form of food consumption could be considerably reduced by effective choices of reducing the percentage of animal products in animal food and replacing meat with plant-based or low-paw print animal products. Japanese government, social scientists and economists are encouraged to estimate how much of their ecological resource base will be required to shift Japanese people and animals' current trajectory onto a sustainable path within the ecological capacity of the country (Kitzes et al., 2008).

\subsection{Dietary energy requirement}

The current literature that investigates the energy requirement of companion animals quantifies the relationship between overfeeding and obesity. Obesity is one of the most common health problems of companion animals (Linder and Freeman, 2010). Recently, the prevalence of companion animal obesity has been increasing (German, 2006; Linder and Freeman, 2010), with studies showing that $22-40 \%$ of companion dogs are overweight (McGreevy et al., 2005). Our results reveal that most of the medium-sized and large dogs consumed more energy than they actually needed for their normal activity. Therefore, owners should give their animals food according to animals' size, activity and health condition because all these factors can influence animals' energy requirement (Bermingham et al., 2010; Bermingham et al., 2014). However, without specific calorie information on labels or guidance from veterinaries, it is difficult for owners to appropriately assess their animal's calorie intake or to feed their animals to achieve and maintain optimal body weight (Linder and Freeman, 2010). Hence, we suggest pet food industries and veterinaries provide more accurate and specific feeding directions regarding animal size, activity, weight and health conditions.

Notably, some owners may feed their animal additional food, such 
as leftover food. Yet, owners should be aware of the danger of feeding additional food to their animals, and the portion of such additional food should be taken into account when determining animals' energy requirement in order to avoid overfeeding (Bermingham et al., 2014). However, due to the growing number of companion animal population in Japan as well as in other countries of the world, the energy consumption by these animals would increase dramatically, even if companion animal owners pay more attention to their feeding activities to their animals. The challenge of satisfying the energy requirements of growing animal population, while at the same time shrinking their total dietary EPP in Japan, is daunting. It is the duty of not only the government but also the pet food industries and the companion animal owners to make the pet ownership sustainable. How to reduce companion animals' dietary EPP, therefore, is significantly important for the promotion of global sustainability for the benefit of all.

\subsection{Options for policies to stimulate companion animals' sustainable resource use}

The EPP directly affects the level of the environmental development. Decision makers concerned about the environmental impacts of companion animals should focus on how to reduce their EPP. Therefore, more government involvement and regulations seem necessary to accomplish this task because knowing whether policy implications permanently affect companion animals' environmental impacts is an important consideration in policy discussions (Ulucak and Lin, 2017). The first premise of reducing companion animals' environmental impacts is to let owners know their animals' huge resource consumption. Therefore, the government and media should carry on a massive and extensive campaign to improve owners' awareness on issues about their animals' environmental impacts. The research aims to quantify animals' environmental impacts and improve sustainable development deserves to be the priority when making educational policy decisions. Taxation is an important basis of the energy policy (Vringer et al., 2016). In order to improve companion animal management and, to some extent, reduce their numbers, companion animal registration and tax should be included in the government tax system; the larger and the more number the companion animals, the more the tax. Such a tax differentiation could be part of a broad tax reform that the Japanese government is currently preparing. "Adopt Instead of Buying a Pet" should be a slogan of any individual who wants to own a pet and the government, as well as the media, should encourage this approach by proper policies (De Lavigne, 2015). Veterinary as a professional practitioner should play a more comprehensive role in avoiding overfeeding and reducing companion animals' environmental impacts by providing specific information about animals' energy requirement. Hence, providing preferential policies (e.g., tax privileges) to improve veterinaries' enthusiasm would be a good choice for the government to reduce companion animals' energy consumption. Additionally, facilitating greater investment to encourage technological innovation in not only pet food industry, but also in agriculture production including finding alternative sources of meat and protein, is essentially important to reduce environmental impacts.

\subsection{Limitations}

Our study is the first to quantify the dietary EPP and GHG emissions of companion dogs and cats in Japan. Therefore, the calculations presented in this research are, without any doubt, characterized by some limitations. For instance, asking respondents to provide the exact body weight and food consumption of their companion animals is impossible if we want to achieve a large sample size. Therefore, we provided the minimum and maximum body weight, as well as the minimum food consumption per unit body weight, which resulted in the large range of the dietary EPP, GHG emissions and energy consumption. However, these data are the best available source for the present EPP studies in
Japan. Additionally, our calculations were based on companion animals' commercial dry food, while there were some owners may prepare pure meat food or other specific food for their animals. Hence, the accuracy of the assessment would profit from more detailed information, while this limitation has also revealed the need to deploy more precise quantitative methods in our follow-up research.

\section{Conclusions and policy implications}

This study quantified the environmental impacts of companion dogs and cats in Japan, with a focus on the dietary EPP, GHG emissions and energy consumption. Our results demonstrate that companion dogs and cats in Japan consumed a significant amount of food resources, resulting in negative environmental impacts such as the huge GHG emissions. Overfeeding and food waste might be a common phenomenon in dog- and cat-owning households in Japan, which inevitably aggravate the burden of environmentally sustainable development. Companion animals' negative impacts on the environment would be more evident with the increase of animal population and the decrease of the environmental capacity. It is recommended that reducing companion animal numbers, replacing large dogs with small dogs or cats and avoiding food waste and overfeeding would considerably reduce companion animals' environmental impacts.

To the best of our knowledge, this is the first study to approximate and quantify the dietary EPP and energy requirement of Japanese companion dogs and cats and evaluate their environmental impacts by analyzing GHG emissions. By utilizing market-wide knowledge of pet food and direct data on pet food consumption, we think our results are more powerful compared to the stochastic data in previous studies. This research contributes to the field of empirical research dealing with the relationship between companion animals and environmental issues and therefore can serve as a baseline for further sustainable development studies. Companion dogs and cats are important to humans because of their benefits on human physical and psychological health (Su and Martens, 2018). Acknowledging their negative impacts on the environment does not mean neglecting their emotional bond with humans. Similarly, the positive relationship between companion animals and owners may not be an acceptable reason for ignoring their negative environmental impacts (Rastogi, 2010). Therefore, the government should re-construct their companion animal keeping policies, pet food industries should re-formulate their feeding directions and companion animal owners should re-think their husbandry activities in order to contribute to sustainable development at national and even global levels.

\section{Acknowledgements}

We thank the reviewers for their valuable comments; these improved the paper. We thank Dr. Naoko Koda for her help in some data collection. We thank all the dog and cat owners for their participation in the survey.

\section{References}

Ahmadi, H.B., Petrudi, S.H.H., Wang, X., 2017. Integrating sustainability into supplier selection with analytical hierarchy process and improved grey relational analysis: a case of telecom industry. Int. J. Adv. Manuf. Technol. 90, 2413-2427.

Allen, K.M., Blascovich, J., Tomaka, J., Kelsey, R.M., 1991. Presence of human friends and pet dogs as moderators of autonomic responses to stress in women. J. Pers. Soc. Psychol. 61, 582.

Alshuwaikhat, H.M., Abubakar, I., 2008. An integrated approach to achieving campus sustainability: assessment of the current campus environmental management practices. J. Cleaner Prod. 16, 1777-1785.

Bermingham, E.N., Thomas, D.G., Cave, N.J., Morris, P.J., Butterwick, R.F., German, A.J., 2014. Energy requirements of adult dogs: a meta-analysis. PLoS One 9, e109681.

Bermingham, E.N., Thomas, D.G., Morris, P.J., Hawthorne, A.J., 2010. Energy requirements of adult cats. Br. J. Nutr. 103, 1083-1093.

Blue, G.F., 1986. The value of pets in children's lives. Childhood Educ. 63, 85-90.

Courcier, E., Thomson, R., Mellor, D., Yam, P., 2010. An epidemiological study of 
environmental factors associated with canine obesity. J. Small Anim. Pract. 51, 362-367.

De Lavigne, G., 2015. Free Ranging Dogs-Stray, Feral or Wild? Lulu Press, Inc.

Du, B., Zhang, K., Song, G., Wen, Z., 2006. Methodology for an urban ecological footprint to evaluate sustainable development in China. Int. J. Sustainable Develop. World Ecol. 13, 245-254.

Eshel, G., Martin, P.A., 2006. Diet, energy, and global warming. Earth Interact 10, 1-17. Ferng, J.-J., 2014. Nested open systems: an important concept for applying ecological footprint analysis to sustainable development assessment. Ecol. Econ. 106, 105-111.

Fleeman, L.M., Owens, E., 2007. Applied Animal Nutrition. Animal Physiotherapy: Assessment, Treatment and Rehabilitation of Animals, pp. 14-31.

Flynn, M., Hardie, E., Armstrong, P., 1996. Effect of ovariohysterectomy on maintenance energy requirement in cats. J. Am. Vet. Med. Assoc. 209, 1572-1581.

Francke, I., Castro, J., 2013. Carbon and water footprint analysis of a soap bar produced in Brazil by Natura Cosmetics. Water Resour. Ind. 1, 37-48.

Galli, A., Wackernagel, M., Iha, K., Lazarus, E., 2014. Ecological footprint: Implications for biodiversity. Biol. Conserv. 173, 121-132.

Geng, Y., Zhang, L., Chen, X., Xue, B., Fujita, T., Dong, H., 2014. Urban ecological footprint analysis: a comparative study between Shenyang in China and Kawasaki in Japan. J. Cleaner Prod. 75, 130-142.

Gerber, P.J., Steinfeld, H., Henderson, B., Mottet, A., Opio, C., Dijkman, J., Falcucci, A., Tempio, G., 2013. Tackling Climate Change Through Livestock: A Global Assessment of Emissions and Mitigation Opportunities. Food and Agriculture Organization of the United Nations (FAO)

German, A.J., 2006. The growing problem of obesity in dogs and cats. J. Nutrit. 136, 1940S-1946S.

González-Vallejo, P., Marrero, M., Solís-Guzmán, J., 2015. The ecological footprint of dwelling construction in Spain. Ecol. Ind. 52, 75-84.

Goodman, L.A. 1961. Snowball Sampling. The Annals of Mathematical statistics, pp. $148-170$.

Headey, B., 1999. Health benefits and health cost savings due to pets: Preliminary estimates from an Australian national survey. Soc. Indic. Res. 47, 233-243.

Headey, B., Grabka, M., Kelley, J., Reddy, P., Tseng, Y.-P., 2002. Pet ownership is good for your health and saves public expenditure too: Australian and German longitudinal evidence. Aust. Soc. Monitor 5, 93.

Hocquette, A., Lambert, C., Sinquin, C., Peterolff, L., Wagner, Z., Bonny, S.P., Lebert, A., Hocquette, J.-F., 2015. Educated consumers don't believe artificial meat is the solution to the problems with the meat industry. J. Integr. Agric. 14, 273-284.

Hopkins, P.D., Dacey, A., 2008. Vegetarian meat: could technology save animals and satisfy meat eaters? J. Agric. Environ. Ethics 21, 579-596.

Iguchi, M., Koga, M., 2015. 12 The state of environment and energy governance in Japan. Environmental Challenges and Governance: Diverse Perspectives from Asia, vol. 37, pp. 219.

Jones, A., Ackerman, N., 2016. Canine and feline nutrition. Aspinall's Complete Textbook of Veterinary Nursing, vol. 145.

Kaushik, S., Médale, F., 1994. Energy requirements, utilization and dietary supply to salmonids. Aquaculture 124, 81-97.

Keyzer, M., Merbis, M., Pavel, I., Van Wesenbeeck, C., 2005. Diet shifts towards meat and the effects on cereal use: can we feed the animals in 2030? Ecol. Econ. 55, 187-202.

Kidd, A.H., Kidd, R.M., 1998. Problems and benefits of bird ownership. Psychol. Rep. 83, $131-138$.

Kitzes, J., Wackernagel, M., Loh, J., Peller, A., Goldfinger, S., Cheng, D., Tea, K., 2008. Shrink and share: humanity's present and future Ecological Footprint. Philos. Trans. R. Soc. London B: Biol. Sci. 363, 467-475.

Knowler, S.P., Kiviranta, A.-M., McFadyen, A.K., Jokinen, T.S., La Ragione, R.M., Rusbridge, C., 2017. Craniometric analysis of the hindbrain and craniocervical junction of chihuahua, affenpinscher and Cavalier King Charles spaniel dogs with and without syringomyelia secondary to Chiari-like malformation. PLoS one 12, e0169898.

Lambrechts, W., Van Liedekerke, L., 2014. Using ecological footprint analysis in higher education: campus operations, policy development and educational purposes. Ecol. Ind. 45, 402-406.

Lilja, M., Baaz, M., Vinthagen, S., 2015. Fighting with and against the time: the japanese environmental movement's queering of time as resistance. J. Civil Soc. 11, 408-423.

Linder, D.E., Freeman, L.M., 2010. Evaluation of calorie density and feeding directions for commercially available diets designed for weight loss in dogs and cats. J. Am. Vet. Med. Assoc. 236, 74-77.

Liu, H., Wang, X., Yang, J., Zhou, X., Liu, Y., 2017. The ecological footprint evaluation of low carbon campuses based on life cycle assessment: a case study of Tianjin, China. J. Cleaner Prod. 144, 266-278.

Mani, V., Gunasekaran, A., Papadopoulos, T., Hazen, B., Dubey, R., 2016. Supply chain social sustainability for developing nations: evidence from India. Resour. Conserv. Recycl. 111, 42-52.

McGreevy, P., Thomson, P., Pride, C., Fawcett, A., Grassi, T., Jones, B., 2005. Prevalence of obesity in dogs examined by Australian veterinary practices and the risk factors involved. Vet. Record-English Ed. 156, 695-701.

Miao, C.-L., Sun, L.-Y., Yang, L., 2016. The studies of ecological environmental quality assessment in Anhui Province based on ecological footprint. Ecol. Ind. 60, 879-883.

Milligan, L., Summers, M., 1986. The biological basis of maintenance and its relevance to assessing responses to nutrients. Proc. Nutr. Soc. 45, 185-193.

Mullis, R.A., Witzel, A.L., Price, J., 2015. Maintenance energy requirements of odor detection, explosive detection and human detection working dogs. PeerJ 3, e767.

Nemecek, T., Weiler, K., Plassmann, K., Schnetzer, J., Gaillard, G., Jefferies, D., GarcíaSuárez, T., King, H., Canals, L.M.I., 2012. Estimation of the variability in global warming potential of worldwide crop production using a modular extrapolation approach. J. Cleaner Prod. 31, 106-117.

Okin, G.S., 2017. Environmental impacts of food consumption by dogs and cats. PLoS One 12 , e0181301.

Qu, X., Li, B., 2013. An Estimation Method of the Carbon Footprint in Manufacturing Logistics Systems. Springer, pp. 657-663 LTLGB 2012.

Rafindadi, A.A., 2016. Revisiting the concept of environmental Kuznets curve in period of energy disaster and deteriorating income: empirical evidence from Japan. Energy Policy 94, 274-284.

Rastogi, N., 2010. The trouble with kibbles: the environmental impact of pet food. Slate. Ravilious, K., 2009. How green is your pet? New Sci. 204, 46-47.

Rees, W.E., 1992. Ecological footprints and appropriated carrying capacity: what urban economics leaves out. Environ. Urbaniz. 4, 121-130.

Reijnders, L., Soret, S., 2003. Quantification of the environmental impact of different dietary protein choices. Am. J. Clin. Nutrit. 78, 664S-668S.

Schwartz, L., 2014. The surprisingly large carbon paw print of your beloved pet. Salon.

Serpell, J., 1991. Beneficial effects of pet ownership on some aspects of human health and behaviour. J. R. Soc. Med. 84, 717-720.

Shi, X., Ma, Y., Wang, Q., Gao, K., Liu, X., 2015. Geo-Informatics in Resource Management and Sustainable Ecosystem.

Su, B., Koda, N., Martens, P., 2018. How Japanese companion dog and cat owners' degree of attachment relates to the attribution of emotions to their animals. PLoS One 13, e0190781.

Su, B., Martens, P., 2017. Public attitudes toward animals and the influential factors in contemporary China. Anim Welfare 26, 239-247.

Su, B., Martens, P., 2018. How ethical ideologies relate to public attitudes toward animals: the Dutch Case. Anthrozoös 31, 179-194.

Swanson, K.S., Carter, R.A., Yount, T.P., Aretz, J., Buff, P.R., 2013. Nutritional sustainability of pet foods. Adv. Nutrit. 4, 141-150.

Thatcher, C., Hand, M., Remillard, R.L., 2010. Small animal clinical nutrition: an iterative processSmall animal clinical nutrition: an iterative process. In: In: Hand, M.S., Thatcher, C.D., Remillard, R.L. (Eds.), Small Animal Clinical Nutrition 5. pp. 3-21.

Tillé, Y., 2006. Simple Random Sampling. Sampling Algorithms, pp. 41-62.

Tilman, D., Balzer, C., Hill, J., Befort, B.L., 2011. Global food demand and the sustainable intensification of agriculture. Proc. Natl. Acad. Sci. 108, 20260-20264.

Ulucak, R., Lin, D., 2017. Persistence of policy shocks to Ecological Footprint of the USA. Ecol. Ind. 80, 337-343.

Vale, Vale, 2009. Time to Eat the Dog? The Real Guide to Sustainable Living. Thames \& Hudson.

Vinnari, M., 2008. The future of meat consumption—expert views from Finland. Technol. Forecast. Soc. Change 75, 893-904.

Vringer, K., van Middelkoop, M., Hoogervorst, N., 2016. Saving energy is not easy: an impact assessment of Dutch policy to reduce the energy requirements of buildings. Energy Policy 93, 23-32.

Wackernagel, M., 1994. Ecological Footprint and Appropriated Carrying Capacity: A Tool for Planning Toward Sustainability (Ph.D. Thesis). School of Community and Regional Planning, The University of British Columbia.

Wackernagel, M., Onisto, L., Bello, P., Linares, A.C., Falfán, I.S.L., Garcıa, J.M., Guerrero, A.I.S., Guerrero, M.G.S., 1999. National natural capital accounting with the ecological footprint concept. Ecol. Econ. 29, 375-390.

Wackernagel, M., Rees, W., 1998. Our Ecological Footprint: Reducing Human Impact on the Earth. New Society Publishers.

Wirsenius, S., Azar, C., Berndes, G., 2010. How much land is needed for global food production under scenarios of dietary changes and livestock productivity increases in 2030? Agric. Syst. 103, 621-638.

Xu, X., Lan, Y., 2017. Spatial and temporal patterns of carbon footprints of grain crops in China. J. Cleaner Prod. 146, 218-227. 